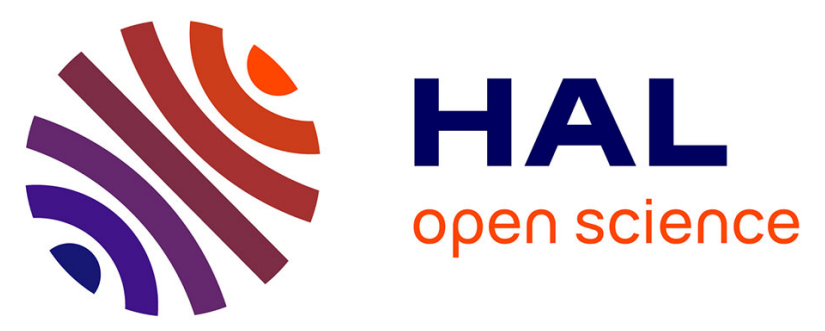

\title{
Prehibernation and hibernation effects on the D-3-hydroxybutyrate dehydrogenase of the heavy and light mitochondria from liver jerboa (Jaculus orientalis) and related metabolism.
}

\author{
Driss Mountassif, Mostafa Kabine, Norbert Latruffe, M'Hammed Saïd El
} Kebbaj

\section{To cite this version:}

Driss Mountassif, Mostafa Kabine, Norbert Latruffe, M'Hammed Saïd El Kebbaj. Prehibernation and hibernation effects on the D-3-hydroxybutyrate dehydrogenase of the heavy and light mitochondria from liver jerboa (Jaculus orientalis) and related metabolism.. Biochimie, 2007, 89 (8), pp.1019-28. 10.1016/j.biochi.2007.04.001 . hal-00259211

\author{
HAL Id: hal-00259211 \\ https://hal.science/hal-00259211
}

Submitted on 13 Mar 2008

HAL is a multi-disciplinary open access archive for the deposit and dissemination of scientific research documents, whether they are published or not. The documents may come from teaching and research institutions in France or abroad, or from public or private research centers.
L'archive ouverte pluridisciplinaire HAL, est destinée au dépôt et à la diffusion de documents scientifiques de niveau recherche, publiés ou non, émanant des établissements d'enseignement et de recherche français ou étrangers, des laboratoires publics ou privés. 


\title{
PREHIBERNATION AND HIBERNATION EFFECTS ON THE D-3-HYDROXYBUTYRATE DEHYDROGENASE OF THE HEAVY AND LIGHT MITOCHONDRIA FROM LIVER JERBOA (JACULUS ORIENTALIS) AND RELATED METABOLISM
}

\author{
Driss Mountassif ${ }^{1}$, Mostafa Kabine ${ }^{1}$, Norbert Latruffe $^{2}$ and M'Hammed Saïd El Kebbaj ${ }^{1}$ \\ ${ }^{1}$ Laboratoire de Biochimie et de Biologie Moléculaire, Faculté des Sciences, Université Hassan II-Aïn Choc \\ - Casablanca, km 8, route d'El Jadida BP. 5366, Casablanca, Morocco. \\ ${ }^{2}$ Laboratoire de Biologie Cellulaire et Moléculaire (GDR-CNRS $n^{\circ}$ 2583), Faculté des Sciences, 6 Bd \\ Gabriel, Université de Bourgogne, 21000 Dijon cedex, France.
}

\begin{abstract}
:
The D-3-hydroxybutyrate dehydrogenase (BDH) (EC 1.1.1.30) from liver jerboa (Jaculus orientalis), a ketone body converting enzyme in mitochondria, in two populations of mitochondria (heavy and light) has been studied in different jerboa states (euthermic, prehibernatingand hibernating). The results reveal: (1) important variations between states in terms of ketones bodies, glucose and lipid levels; (2) significant differences between the BDH of the two mitochondrial populations in term of protein expression and kinetic properties. These results suggest that BDH leads an important conformational change depending on the physiological state of jerboa. This BDH structural change could be the consequence of the lipid composition modifications in inner mitochondrial membrane leading to changes in BDH catalytic properties.
\end{abstract}

\section{Keywords:}

D-3-hydroxybutyrate dehydrogenase, Jerboa (Jaculus orientalis), euthermic, prehibernation and hibernation states, heavy and light mitochondria, isoforms.

\begin{abstract}
Abbreviations:
AcAc, Acetoacetate; BDH, D- $\beta$-Hydroxybutyrate dehydrogenase; DL-BOH, DL-3hydroxybutyrate; CPK, Creatine phosphokinase; EDTA, Ethylenediamine tetraacetic acid ; ELISA, Enzyme-Linked Immunosorbent Assay; GOT, Glutamate Oxalate Transaminase; GPT, Glutamate Pyruvate Transaminase; HDL, High Density Lipoprotein; Hepes, 4-(2-hydroxyethyl)-1-piperazine ethane sulfonic acid; LDL, Low Density Lipoprotein; Mes, 4-N-morpholinoethanesulfonic acid ; $\operatorname{NAD}(\mathrm{H})$, Nicotinamide adenine dinucleotide oxidized / (reduced) forms ; SDS-PAGE, sodium dodecyl sulfate - polyacrylamide gel electrophoresis; TCA, Trichloroacetic acid; TMB, Tetramethyl benzidine; Tris, Trihydroxymethyl-aminomethane.
\end{abstract}




\section{Introduction:}

Hibernation is a strategy adopted by several mammals in order to survive the lack of food and the low ambient temperatures. This state requires a special adaptation of cell metabolism with physiological change that necessitates a strict control of lipid metabolism particularly, since lipids play a critical role in supplying the energy requirements. The mitochondria play an important role in energy production namely during hibernation. They are also the site of the ketone bodies production. These compounds, which result from the degradation of fatty acids, play a crucial role in the energy metabolism of extrahepatic tissues. The interconversion of ketone bodies is made by D-3-hydroxybutyrate dehydrogenase (BDH) (EC 1.1.1.30) first described in dog liver tissue (Wakeman and Dakin, 1909). In eukaryotic cells, BDH is an inner mitochondrial membrane bound enzyme, tightly associated with the NAD-linked electron transport chain, where its active site is located on the matrix side of mitochondria (Wise and Lehninger, 1962; Nielsen et al., 1973; Latruffe and Gaudemer, 1974; Gaudemer and Latruffe, 1975; Mc Intyre et al., 1978). BDH is synthesized in the cytoplasm as a precursor with a larger size and post translationally imported into mitochondria involving the processing of its N-terminus presequence (Kante et al., 1987). BDH was largely studied in several organisms: Rhodopseudomonas spheroides (Bergmeyer et al., 1967), beef heart (Nielsen et al., 1973), rat liver (Latruffe et al., 1974), ruminant's heart and liver (CherkaouiMalki et al., 1992) and dromedary liver (Nasser et al., 2002). The molecular mass of the subunit size of the purified BDH was $31.5 \mathrm{KDa}$ for bovine heart, rat liver, and rat brain mitochondria (Bock and Fleischer, 1975; Vidal et al., 1977; McIntyre et al., 1988; Zhang and Churchill, 1990) and about $67 \mathrm{KDa}$ for dromedary liver (Nasser et al., 2002). Purified BDH is devoid of lipid and can insert spontaneously and unidirectionally into performed phospholipid vesicles or natural membranes (McIntyre et al., 1979). It has previously been proposed that activation of BDH by PhosphatidylCholine (PC) containing liposomes involves an allosteric mechanism (Sandermann et al. 1986), whereby PC enhances coenzyme binding (Rudy et al., 1989). The primary sequence of BDH was initially determined for the enzyme from rat liver (Churchill et al., 1992) and for the enzyme from human heart (Marks et al., 1992) by cDNA cloning. The mature form of this enzyme consists of 297 amino acids and the Northern blot analysis identifies a 1.3-kilobase mRNA (Marks et al., 1992). A comparison of the BDH amino acid sequences with other reported sequences reveals a homology with the superfamily of short-chain alcohol dehydrogenases. The N-terminal of the enzyme include the coenzyme binding domain and putative active site conserved residues. The $\mathrm{C}$-terminal of BDH and other family members show little sequence homology and this region likely contains elements responsible for the binding of $\mathrm{BOH}$. The catalytic activity of the enzyme is lecithin-dependent (Sekuzu et al., 1961; Gazzoti et al., 1964). As reported by Williamson et al., 1971, in liver, the enzyme, in the presence of $\mathrm{NADH}$, catalyses the converstion of acetoacetate into D-3hydroxybutyrate which is transported through the blood stream to peripheral tissues, i.e. brain, heart, kidney, etc. In extrahepatic tissues, D-3-hydroxybutyrate is converted into acetoacetate in the presence of NAD+. Acetoacetate is then consummed, after its conversion to acetyl-CoA, by the respiratory chain as fuel for ATP production, or after formation of acetoacetyl-CoA, for fatty acid synthesis. A catalytic mechanism of the interconversion of D-3-hydroxybutyrate and acetoacetate in both liver and peripheral tissues has been previously proposed by our group (El kebbaj and Latruffe, 1997).

The jerboa (Jaculus orientalis), a nocturnal herbivorous rodent living in the subdesert highland of Morocco, was chosen for our study due to the following reasons: This rodent is an appropriate organism to study metabolic regulation due to its remarkable resistance to heat, arid conditions and especially to cold. Also, this rodent is a true hibernator (El Hilali and Veillat, 1979) developing obesity by accumulating fat during its prehibernation period. Its fat is eliminated during hibernation leading to a high production via BDH of D-3-hydroxybutyrate to serve as an energy source in addition to carbohydrates (Kante et al., 1990).

Recently, we demonstrated the existence of two mitochondrial populations (Mountassif et al., 2006). The population of large mitochondria referred to as "heavy" $(0.85 \mu \mathrm{m}$ in length and 0.5 
$\mu \mathrm{m}$ in width) and the population of small mitochondria referred to as "light" $(0.35 \mu \mathrm{m}$ in length and $0.25 \mu \mathrm{m}$ in width); also, we reported that BDH of the two mitochondrial populations were different in terms of activities, content and physico-chemical properties. Their differences can, be correlated with the lipid composition of the mitochondrial membrane, which would modify both the BDH structure and activity, as lecithin requiring enzyme and the pre-BDH import and its insertion into the inner mitochondrial membrane.

To explore the mechanisms of the regulatory processes associated with prehibernation and hibernation states, we performed a comparative study of these physiological states in terms of plasma analyses and the comparison of $\mathrm{BDH}$ expression from both heavy and light liver mitochondria in euthermic (active), prehibernating and hibernating jerboas.

\section{Materials and methods:}

Animals:

Adult greater Egyptian jerboas (Jaculus orientalis, Rodentia, Dipodidae) (120-150 g, 4-6 months old), were captured in the area of Engil Aït Lahcen (in subdesert East Moroccan highland). They were adapted to laboratory conditions during 3 weeks at a temperature of $22^{\circ} \mathrm{C}$ with food (salad and rat chow), and water ad libitum before they were killed. The light cycle during the experiment was set to $14 \mathrm{~h}$ light and $10 \mathrm{~h}$ dark.

\section{Induced hibernation:}

Prehibernating $(\mathrm{PH})$ and hibernating $(\mathrm{H})$ states were performed as described by Montoya et al., 1979 and Baddouri et al., 1986: A group of 8 animals called (PH) (4 per cage) was kept with food in a cold room $\left(6^{\circ} \mathrm{C}\right)$ for 3 weeks. A second group $(\mathrm{H})(\mathrm{n}=4)$ was housed as $\mathrm{PH}$ group but at the end of 3 weeks of the prehibernation period, the food was removed leading to hibernation established for 1 week. After 6 days of hibernation, animals were sacrificed. A third group of animals considered as euthermic $(n=4)$ was remained at $22^{\circ} \mathrm{C}$ and called active $(A)$.

\section{Plasma analyses:}

Immediately after jerboa decapitation, the blood was collected and centrifuged for $10 \mathrm{~min}$ at $600 \mathrm{~g}$ and the plasma portion was removed and frozen at $-20^{\circ} \mathrm{C}$ until assays. Before assay, the plasma samples were centrifuged at XXX g for 5 min.

The ketonemia (BOH level) was estimated by the technique described by Williamson et al., (1962) slightly adapted and modified by our laboratory as follow; the serum was deproteinised with $1 \mathrm{~N}$ perchloric acid mixed with serum $(\mathrm{v} / \mathrm{v})$; the precipitate of proteins was eliminated by centrifugation $(1200 \mathrm{x} \mathrm{g}$ for $10 \mathrm{~min})$. The supernatant was neutralized with $\mathrm{KOH} 1 \mathrm{~N}$ and centrifuged. The medium of BDH measurement was: $100 \mu \mathrm{g}$ of protein in a medium containing: 6 $\mathrm{mM}$ potassium phosphate $\mathrm{pH} 8,0.5 \mathrm{mM}$ EDTA, $1.27 \%(\mathrm{v} / \mathrm{v})$ redistilled ethanol, $0.3 \mathrm{mM}$ dithiothreitol, in the presence of $2 \mathrm{mM} \mathrm{NAD}+$ (Sigma) and $2.5 \mu \mathrm{g}$ rotenone (final addition) and $25.38 \%$ Hydrazine. The absorbance of reduced NAD+ (NADH) was measured at $340 \mathrm{~nm}$ at time 0 immediately after that $250 \mu \mathrm{l}$ of supernatant were added. After one hour of incubation at $37^{\circ} \mathrm{C}$, the absorbance was again measured. One can consider that after $60 \mathrm{~min}, \mathrm{BOH}$ is completely oxidized, and that AcAc produced is combined with hydrazine leading the reaction irreversible.

$[\mathrm{BOH}]=[($ absorbance at $60 \mathrm{~min}-$ absorbance at $0 \mathrm{~min}) / 6220] \times$ (total volume of measure / volume of serum) $\mathrm{x}$ factor of dilution of serum.

The determination of glycemia, urea, total bilirubine, creatinine, total cholesterol, HDL, LDL, triglycerides, CPK and aminotransaminases (GOT and GPT) was carried out by Laboratoire des Analyses Médicales (Centre National de Transfusion Sanguine, Casablanca). 


\section{Liver mitochondria and mitoplast isolation:}

The jerboas were decapitated and the liver was rapidly removed for mitochondrial extraction according to Fleischer et al. (1979). This method allows the preparation of the two mitochondrial populations.

The mitoplasts (outer mitochondrial membrane-free mitochondria) preparation was done according to the method described by Kielley and Bronk (1958). Liver mitochondria were swelled in a $20 \mathrm{mM}$ phosphate buffer at $0.5 \mathrm{ml} / \mathrm{mg}$ of protein for $30 \mathrm{~min}$ at $0^{\circ} \mathrm{C}$. The medium was then centrifuged at $12000 \mathrm{~g}$ for $30 \mathrm{~min}$. The mitoplasts were collected in the pellet.

\section{Protein assay:}

Protein content was measured according to the Bradford (1976) procedure, using bovine serum albumin (BSA) as standard.

\section{Phospholipid extraction and composition:}

Phospholipids were extracted according to the technique of Rouser and Fleischer (1967). One volume of mitoplasts was added to chloroform $/$ methanol $/ 0.8 \% \mathrm{KCl}(13.3 / 6.7 / 4.2 ; \mathrm{v} / \mathrm{v} / \mathrm{v})$. The mixture was homogenized with an Ultraturrax at 7,500 rpm for $3 \mathrm{~min}$. After sedimentation, the organic phase was recovered and $0.8 \% \mathrm{KCl} / \mathrm{methanol} / \mathrm{chloroform}(47 / 48 / 3 ; \mathrm{v} / \mathrm{v} / \mathrm{v})$ was added. The chloroform phase was then concentrated in a rotary evaporator. The amount of phospholipids was determined by measuring the phosphorus concentration according to Chen et al. (1956).

Ten microlitres of sample were mineralized with $450 \mu \mathrm{L}$ of $70 \%$ perchloric acid for $60 \mathrm{~min}$. After $10 \mathrm{~min}, 4.5 \mathrm{~mL}$ of water, $500 \mu \mathrm{L}$ of $2.5 \%$ ammonium molybdate and $500 \mu \mathrm{L}$ of $10 \%$ ascorbic acid were added. The mixture was then incubated for $5 \mathrm{~min}$ in boiling water for color development. After 10 min of cooling, the absorbance was measured at $820 \mathrm{~nm}$ against a blank containing all the reagents. A standard range from 0 to $5 \mu \mathrm{g}$ of phosphorus was established with $\mathrm{KH}_{2} \mathrm{PO}_{4}$ at $2 \mu \mathrm{g} / \mathrm{mL}$.

Thin layer chromatography was carried out on dried silicagel plates $(20 \mathrm{~cm} \times 20 \mathrm{~cm})$. Phospholipid phosphorus $(40 \mu \mathrm{g})$ was loaded, and plates were developed with chloroform/methanol/water $(65 / 25 / 4 ; \mathrm{v} / \mathrm{v} / \mathrm{v})$. Spots were revealed with 2, 7-dichlorofluoresceine. The bands were scraped off, mineralized and their phosphorus content was measured.

\section{Enzyme assays:}

Subcellular marker enzymes were assayed according to the following methods: succinate dehydrogenase (King, 1967) for mitochondria; palmitoyl-CoA oxidase (Lazarow and De Duve, 1976) for peroxisomes; NADPH-cytochrome c reductase (Beaufay et al., 1974) for microsomes and glyceraldehyde 3-phosphate dehydrogenase (Serrano et al., 1991) for cytosol.

$\mathrm{BDH}$ activity was measured at $37^{\circ} \mathrm{C}$ as described by Lehninger et al. (1960), by monitoring NADH production at $340 \mathrm{~nm}\left(\varepsilon=6.22 \times 10^{3} \mathrm{M}^{-1} \cdot \mathrm{cm}^{-1}\right)$ using $100 \mu \mathrm{g}$ of protein in a medium containing: $6 \mathrm{mM}$ potassium phosphate at $\mathrm{pH} 8,0.5 \mathrm{mM}$ EDTA, 1.27\% (v/v) redistilled ethanol, 0.3 $\mathrm{mM}$ dithiothreitol, in the presence of $2 \mathrm{mM}$ NAD+ (Sigma-Aldrich) and $2.5 \mu \mathrm{g}$ rotenone (final addition). The reaction was started by the addition of DL-3-hydroxybutyrate (Sigma) to $10 \mathrm{mM}$ final concentration.

\section{BDH kinetic studies:}

Initial velocities were measured by varying the concentration of $\mathrm{BOH}$ (from 2.5 to $10 \mathrm{mM}$ ) or NAD+ (from 0.5 to $2 \mathrm{mM}$ ). Michaelis constants $(\mathrm{Km})$, dissociation constants $(\mathrm{KD})$ and maximal velocity for the oxidation of $\mathrm{BOH}$ and the reduction of $\mathrm{NAD}+$ by the $\mathrm{BDH}$ were obtained by mathematical analysis following Cleland (1963).

\section{Determination of optimal $\mathrm{pH}$ and temperature dependent $\mathrm{BDH}$ activity:}

The effect of $\mathrm{pH}$ on $\mathrm{BDH}$ activity was studied in range from $\mathrm{pH} 4$ to $\mathrm{pH} 10$ using a mixture of different buffers (Tris, Mes, Hepes, potassium phosphate and sodium acetate). 
Temperature effects were characterized by activation and denaturation processes :

For activation, the buffered medium containing $6 \mathrm{mM}$ potassium phosphate $\mathrm{pH} 8,0.5 \mathrm{mM}$ EDTA, $1.27 \%(\mathrm{v} / \mathrm{v})$ redistilled ethanol was incubated for $2 \mathrm{~min}$ at temperatures from 5 to $80^{\circ} \mathrm{C}$. Then, $2.5 \mu \mathrm{g}$ of rotenone, $2 \mathrm{mM}$ of $\mathrm{NAD}^{+}$and $100 \mu \mathrm{g}$ of protein were added. The reaction was started immediately by the addition of $20 \mathrm{mM}$ of BOH.

For denaturation, $100 \mu \mathrm{g}$ of liver mitochondrial protein were incubated at temperatures from 5 to $80^{\circ} \mathrm{C}$ for $2 \mathrm{~min}$ in medium containing $6 \mathrm{mM}$ potassium phosphate $\mathrm{pH} 8,0.5 \mathrm{mM}$ EDTA, 1.27\% $(\mathrm{v} / \mathrm{v})$ redistilled ethanol. Then, $2.5 \mu \mathrm{g}$ of rotenone and $2 \mathrm{mM}$ of $\mathrm{NAD}^{+}$were added and the enzymatic activity was measured by the later addition of $20 \mathrm{mM}$ of $\mathrm{BOH}$ after $2 \mathrm{~min}$ of incubation at $37^{\circ} \mathrm{C}$.

A BDH Arrhenius-plot was obtained by measuring the enzymatic activity at temperatures from 5 to $40^{\circ} \mathrm{C}$ and analyzed as described by Raison (1973).

\section{Western-blotting:}

After SDS-PAGE (12\%) (Laemmli, 1970) and subsequent transfer to nitrocellulose (Towbin et al., 1991), the mitochondrial proteins $(50 \mu \mathrm{g})$ were exposed to a 1:100 dilution of monospecific polyclonal anti-BDH antibody (BDH rat liver) and detected with the secondary antibody of antirabbit, IgG peroxidase conjugate (diluted 1:2500) (Promega).

\section{Enzyme-Linked immunosorbent assay:}

The ELISA method was performed according to Kemeny (1991). Mitochondrial proteins (10 $\mu \mathrm{g})$ were exposed to 1:100 dilution of monospecific polyclonal anti-BDH antibody (BDH rat liver) and detected with the secondary antibody of anti-rabbit, IgG peroxidase conjugate (diluted 1:2500) (Promega) and the absorbance at $410 \mathrm{~nm}$ was measured with an ELISA reader after addition of tetramethyl benzidine (TMB) (Sigma).

\section{Immunofluorescence staining:}

The jerboas were decapitated and the livers were immediately removed, fixed in Bouin liquid and embedded in paraffin. $4 \mu \mathrm{m}$ sections were rinsed with PBS, and then blocked with $1 \%$ bovine serum albumin (BSA) in PBS (1\% BSA-PBS). Sections were then incubated in the primary antibody (1/100) (rabbit anti-BDH of rat) at room temperature for 60 minutes, washed for 5 min with three changes of PBS, and incubated in the fluorescence-labeled goat secondary antibody anti rabbit IgG solution (Sigma) 1/100 for 60 minutes. Sections were then washed for 5 min with three changes of PBS. Fluorescence-stained sections were examined under an epifluorescence microscope (Olympus). Evans blue was used as against dye, it appears in red. BDH appears in yellow.

\section{Statistical analysis:}

In each assay, the experimental data represent the mean of four independent assays \pm SEM. Means were compared using the Student $t$-test. Differences were considered significant at $\mathrm{p}<0.05$ and very significant at the level $\mathrm{p}<0.01$.

\section{Results:}

\section{Plasma analysis:}

Table 1 reports the results of plasma analysis from the three physiological states of jerboa, euthermic, prehibernating and hibernating. We see a significant increase at the jerboa hibernating state compared to euthermic ones for the following parameters: bilirubine level (x 5.1), ketonemia (D-3-hydroxybutyrate level) (x 3.7), urea level (x 1.7) and HDL cholesterol (x 1.27). In contrast, there is a significant decrease in glycemia (x 0.64) and triglycerides level (x 0.56) were found. No changes were observed for GOT, GPT, CPK activities and total cholesterol, LDL and creatinine levels. 
Biochemical characterization of mitochondrial populations of jerboa at different states:

The two mitochondrial populations, heavy and light fractions were isolated from liver at different jerboa states (euthermic (A), prehibernating $(\mathrm{PH})$ and hibernating $(\mathrm{H})$ ). In Table 2, the relative activities of subcellular marker enzymes in the two mitochondrial fractions were reported. As one can see, the two fractions present high mitochondria content with a low contamination by peroxisomes, microsomes and cytosol. From the data, the purity is estimated at $72 \%, 80 \%, 78 \%$, and $86 \%, 78 \%, 80 \%$ for heavy and light mitochondria at euthermic, prehibernating and hibernating jerboa states respectively.

The table 2 shows also a significant decrease of three markers at the hibernating state compared to the euthermic ones: succinate dehydrogenase ( $\mathrm{x}$ 0.69), NADPH cytochrome $\mathrm{c}$ reductase (x 0.69) and glyceraldehyde-3-phosphate dehydrogenase (x 0.76). But, a significant increase was found in peroxisomal palmitoyl CoA oxidase activity (x 1.26) at the hibernating state compared to the euthermic ones.

Determination of BDH physicochemical parameters of mitochondrial populations at different jerboa states:

The optimal $\mathrm{pH}$ of the $\mathrm{BDH}$ activity of the two mitochondrial populations at different states is identical and equal to 8 (not shown).

The optimal temperature for $\mathrm{BDH}$ activity is $35^{\circ} \mathrm{C}$ for heavy mitochondria and $40^{\circ} \mathrm{C}$ for light ones at euthermic state and it is equal to $40^{\circ} \mathrm{C}$ for the two mitochondrial populations at prehibernating and hibernating states (not shown).

$\mathrm{BDH}$ kinetic parameters from the heavy and light mitochondria (Vmax, $\mathrm{K}_{\mathrm{m}} \mathrm{BOH}, \mathrm{K}_{\mathrm{m}} \mathrm{NAD}^{+}$and $\mathrm{K}_{\mathrm{D}} \mathrm{NAD}^{+}$) at different jerboa states were reported in Table 3. Interestingly, the specific activity of the $\mathrm{BDH}$ from the heavy mitochondria is 2.77 -fold higher than that from the light mitochondria at euthermic state. But, in prehibernating state, the BDH activity from light mitochondria is 1.56-fold higher than that from the heavy ones. In hibernating state, the both of BDH activities are identical. The table 3 also shows that the BDH activity from heavy mitochondria is 0.40 -fold lower and 2.68 fold higher at prehibernating and hibernating states respectively than that at euthermic state. For the $\mathrm{BDH}$ activity from the light mitochondria, it's 1.77 and 8.40 -fold higher at prehibernating and hibernating states respectively than that at euthermic state.

Moreover, the kinetic constants with respect to the $\mathrm{NAD}^{+}$and $\mathrm{BOH}$ are higher in the light mitochondria than in the heavy ones (x 1.8 for the $\mathrm{K}_{\mathrm{m}} \mathrm{NAD}+$, x 1.4 for the $\mathrm{K}_{\mathrm{D}} \mathrm{NAD}+$, x 2.1 for $\mathrm{K}_{\mathrm{m}} \mathrm{BOH}$ ). The table 3 also shows that in prehibernating state, the $\mathrm{K}_{\mathrm{m}} \mathrm{NAD}+$ from light mitochondria is 1.62-fold higher than that in euthermic state and the $\mathrm{K}_{\mathrm{D}} \mathrm{NAD}+$ from heavy and light mitochondria respectively at hibernating state is 4.29 and 5.18-fold higher than that at euthermic state.

Arrhenius-plots were carried out for the two mitochondrial populations at different jerboa states (figure 1). Interestingly, the plots show a break at $30^{\circ} \mathrm{C}$ for $\mathrm{BDH}$ from heavy mitochondria at euthermic and hibernating states and at $25^{\circ} \mathrm{C}$ for $\mathrm{BDH}$ from light mitochondria at prehibernating state. For other BDH mitochondrial populations no changes were found.

\section{BDH protein expression}

The BDH protein expression was approached in the three physiological states of jerboa both in heavy and light mitochondria by western-blotting (Fig. 2B A) and ELISA (Fig. 2C B). This amount of BDH is higher in the heavy mitochondria than that in the light ones at euthermic state. At prehibernating state, it is identical between the two mitochondrial populations but lower in the heavy mitochondria compared to euthermic state. At hibernating state, the BDH amount is higher for both mitochondrial populations compared to euthermic and prehibernating states.

In order to confirm in situ the differences observed in BDH protein expression (figure 2), jerboa liver sections $(4 \mu \mathrm{m})$ were revealed by the anti-BDH and fluorescence-labeled secondary antibody. The BDH appears yellow in sections. As one can see in figure 3, the yellow points decrease at the prehibernating state (B) and increase at the hibernating state (C) compared to 
euthermic ones (A).

Phospholipids composition of heavy and light mitoplasts

In order to correlate the causes of differences observed in BDH kinetic parameters and Arrhenius-plots, the content of inner membrane phospholipids of different mitochondrial populations was determined. Table 4 shows that at euthermic state (reported in Mountassif et al., 2006), the two mitochondrial fractions with the amount of phosphatidylcholine being significantly greater in heavy mitochondria than in light ones (x 1.64). No differences were observed for phosphatidylinositol, phosphatidylserine and cardiolipin. At prehibernating state, the amount of phosphatidylethanolamine is much lower (x 0.39) and cardiolipin is largely higher (x 2.18) in heavy mitochondria than in light mitochondria at hibernating state. Table 4 shows also that phosphatidylethanolamine of heavy mitochondria decreases (x 0.47 ) significantly at prehibernating state compared to euthermic ones but cardiolipin and phosphatidylcholine increase (x 0.71 and 0.77) respectively. At hibernating state, cardiolipin of heavy mitochondria decreases ( $\mathrm{x} 0.30$ ) compared to euthermic state. Also, phosphatidylcholine of light mitochondria increases at prehibernating state $(\mathrm{x} 0.50)$ and at hibernating state (x 0.70$)$ compared to euthermic ones.

Interestingly, the amounts of phosphatidylinositol and phosphatidylserine are quite high and were unchanged for all the isolated mitochondrial.

\section{Comparison of impact of prehibernation and hibernation on BDH activities in jerboa and rat}

In order to show that variations in $\mathrm{BDH}$ activity found in different physiological states of jerboa were particulars to hibernator animals, we compared the response of rat (not hibernating animal) submitted at the same conditions of jerboa in term of BDH liver activity. The results reported in table 5 show a low changes in rat BDH activity compared to jerboa while passing from one state to another. Indeed, at euthermic state, BDH activity from the heavy mitochondria is 2.77fold higher than that from the light ones for jerboa and 1.87-fold for rat. For jerboa, BDH activity from heavy mitochondria decreases (x 0.4) and increases (x 2.68) at prehibernating and hibernating states respectively, but for rat, no changes were observed. Also, BDH activity from light mitochondria increases (x 2.41 and x 2.21) at prehibernating and hibernating states respectively compared to euthermic ones for rat while it increases for jerboa (x 1.77 and x 8.40).

\section{Discussion:}

Hibernation is an adaptive strategy for some mammalian species to conserve energy in cold or unfavourable environments related to food availability. These mammals can reduce dramatically their basal metabolic, heart, and respiratory rates as well as their body temperature during hibernation (Magnus and Henderson, 1988; Weekley, 1995). Among mammalian hibernators, Jaculus orientalis is an excellent model for hibernation research due to its small body size and distinct behavioural pattern in relation to hibernation. Also, it's a true hibernator (El Hilali and Veillat, 1979) developing obesity by accumulating fat during its prehibernation period. Its fat is eliminated during hibernation leading to a high production of D-3-hydroxybutyrate to serve as an energy source in addition to carbohydrates (Kante et al., 1990). Its annual cycle consists of two phases, the summer season during which squirrels reproduce and accumulate fat, and the hibernating phase which is composed of alternating dormancy and arousal bouts (El Hilali and Veillat, 1979).

The changes involved in hibernation are precisely controlled and can only be reverted by internally-driven mechanisms, which suggests a specific biochemical regulation.

In this work, we report a comparative study of plasma metabolites on jerboa at different states (euthermic or active, prehibernating and hibernating) and the comparison of the BDH from the heavy and light mitochondria, in terms of kinetic parameters and content at these states.

The plasma analysis (table 1) indicates a significant increase at the jerboa hibernating state compared to euthermic ones in ketonemia and a significant decrease in glycemia and triglycerides 
level. This could be with the consumption of glucose (first energy source) and stimulation of lipolysis leading to an increase in liver ketone bodies production and their passage into the blood. A raise of lipolysis has been previously proposed as a consequence of starvation in squirrels (Krilowicz, 1985). The table 1 shows a highly increase in urea and bilirubine levels with can results of the fact that jerboa does not urinate and defecate during hibernation, so the urea and bilirubine were concentred in blood. Also, we found a significant increase in HDL cholesterol can protect jerboa life since HDL is the best protector agent against atherosclerosis which can be developed during hibernation and caused by the weak blood circulation due to the low body temperature and low number of cardiac beats.

The isolation of two mitochondrial populations, heavy and light fractions, from liver at different jerboa states (euthermic $(\mathrm{A})$, prehibernating $(\mathrm{PH})$ and hibernating $(\mathrm{H})$ reveals a significant decrease of three subcellular markers at the hibernating state compared to the euthermic ones: succinate dehydrogenase, NADPH cytochrome c reductase and glyceraldehyde-3-phosphate dehydrogenase. For this latter, similar results were found in jerboa skeletal muscle (Soukri et al., 1995, 1996). This decrease can be explained by the fact that hibernation causes a reduction in body activities, including metabolic rate and body temperature is maintained within a few degrees above ambient temperatures. On the other hand, we found a significant increase in peroxisomal palmitoyl CoA oxidase activity at the hibernating state compared to the euthermic ones. This increase can be linked to the stimulation of lipolysis of fat accumulated during prehibernation period in order to oxidize fatty acids and subsequently produce ketone bodies (principal fuel consumed during hibernation).

Table 3 reveals interesting differences between $\mathrm{BDH}$ from heavy and light liver mitochondria at different jerboa states. We found that BDH activity is higher in heavy mitochondria than in light ones at euthermic state. In the other hand, at prehibernating and hibernating states, $\mathrm{BDH}$ activity is higher in light mitochondria than in heavy ones. We can suggest that cold exposure influences and increases light mitochondrial BDH biogenesis because it is more stable than heavy mitochondria. In previous study, we showed that BDH from the light mitochondria were more thermostable at different temperatures than the heavy ones (Mountassif et al., 2006). Table 3 indicate that $\mathrm{BDH}$ activity from heavy mitochondria decreases at prehibernating state and increases at hibernating state compared to euthermic ones while BDH activity from light mitochondria slighly increases lowly at prehibernating state but highly at hibernating conditions.

The determination of kinetic parameters indicated that the heavy and the light mitochondrial $\mathrm{BDH}$ at different jerboa states behave differently (Table 3). Indeed, the affinity of the BDH from heavy mitochondria with respect to the $\mathrm{NAD}^{+}$and $\mathrm{BOH}$ is stronger than from the light ones at euthermic state (Mountassif et al., 2006). In the prehibernating state, its affinity decreases (i.e. Km, $\mathrm{KD}$ increases) with respect to the $\mathrm{NAD}^{+}$and are higher in the light mitochondria. In the hibernation, the two $\mathrm{BDH}$ have similar affinities to $\mathrm{NAD}^{+}$and to $\mathrm{BOH}$ and were better compared to the euthermic state.

The differences in kinetic parameters can be the consequences of BDH conformational structure changes. The results of figure 3 support the existence of different BDH conformation. Indeed, Arrhenius-plots show a break at $30^{\circ} \mathrm{C}$ for $\mathrm{BDH}$ from heavy mitochondria at euthermic and hibernating states and at $25^{\circ} \mathrm{C}$ for $\mathrm{BDH}$ from light mitochondria at prehibernating state. For other situations no changes were found.

The differences observed might be caused either by the amount of BDH-which is different between the mitochondrial populations-or by the fact that the organelle phospholipid composition change since BDH is a lipid-dependent enzyme. In order to explain the differences, western blotting, ELISA (figure 2) and BDH immunofluorescence staining (figure 3) were done. The results obtained reveal a low decrease at prehibernating state and a high increase in BDH expression at hibernating ones. BDH activity is necessary during hibernation to produce ketone bodies used by all jerboa tissues to generate energy. Thus, the differences of BDH activity between the two populations of mitochondria at different jerboa states appear to be due to the amount of BDH present. 
The analysis of BDH mRNA level by northern blotting for different states showed no significant variation (Kabine et al., 2003). So, wee can postulate that variations in BDH expression observed would be due to a post-transcriptional regulation.

The phospholipid composition of heavy and light mitoplasts at different jerboa states were significantly different especially concerning phosphatidylcholine, an activator of BDH (El Kebbaj et al., 1985; Loeb-Hennard and Mc Intyre, 2000), phosphatidylethanolamine and cardiolipin (table 4). Previous studies on the interactions of BDH with pospholipids (Gazzoti et al., 1964; McIntyre et al., 1978; Berrez et al., 1984; Kante et al., 1990) have demonstrated that the composition of membrane phospholipids induced structural modifications of BDH. The local environment of the protein may result in an important kinetic change. A change of physical properties of the mitochondrial membrane related to the hibernation process has been also reported in ground squirrel (Raison and Lyons, 1971). Thus, the differences observed in BDH kinetic parameters (table 3 ) and BDH temperature-dependent activation between mitochondrial populations appear to be due to the differences in phospholipid composition of the inner mitochondrial membrane.

In order to show that all variations found in different physiological states of jerboa were particulars to hibernator animals, we compared the liver BDH activity in rat (not hibernating animal) submitted at the same conditions of jerboa. The results obtained (table 5) show only a low changes in rat BDH activity compared to jerboa while passing from one state to another. While rats die after 7 days of hibernating conditions (e.g. cold and starved), in contrast jerboas can resist, probably because they activate lipogenesis during prehibernation in order to accumulate fat and stimulate lipolysis during hibernation in order to generate ketone bodies. In addition, jerboas have a temperature regulation system and adapt their heart beating which allows him to resist and support the cold conditions contrary to the rat (Hooper and El Hilali, 1972).

In conclusion, prehibernation and hibernation of jerboa lead to regulation of liver mitochondrial BDH. The enzyme activity as well as kinetic parameters are varying according to physiological states of jerboa (euthermic, prehibernating and hibernating). This regulation of BDH activity would lead to a change in plasma D-3-hydroxybutyrate level in order to adapt energy metabolism in peripheral tissues. Our results reveal that the distinct enzymatic forms of liver BDH in jerboa are subjected to differential regulation depending on the state. This regulation could be a result of protein expression and modifications of mitochondrial membrane composition.

\section{ACKNOWLEDGMENTS:}

This work was supported by the Regional Council of Burgundy and IFR $n^{\circ} .92$, and by the « Programme Thématique d'Appui à la Recherche Scientifique-Morocco, Biologie no.134 », and by the « Action intégrée franco-marocaine MA/05/134 ».

\section{References:}

Baddouri, K.H., and El Hilali, M., 1986. Secretion of antidiuretic hormone and renal function during the awakening of Jaculus orientalis from hibernation. J Physiol. 81, 202-208.

Beaufay, A., Amar-Costee, A., Thines-Sempoux, D., 1974. Wibo-Robi, M. Berthet, J. Analytical study of microscornes and isolated subcellular membranes front rat liver. III. Subfractionation of microsomal fraction by isopycnic and differential centrifugation in density gradients, J. Cell. Biol. 81, 213-231.

Bergmeyer, H.U., Gawehn, K., Klotzsch, H., Krebs, H.A., Williamson, D.H., 1967. Purification and properties of crystalline 3-hydroxybutyrate dehydrogenase from Rhodopseudomonas spheroides. Biochem J. 102, 423-431.

Berrez, J.M., El Kebbaj, M.S., Latruffe, N., Duroc, R., Gaudemer, Y., 1984. Quantitative approach of the interactions of D- $\beta$-hydroxybutyrate dehydrogenase with phospholipids, C.R. Soc. Biol. $178,467-473$.

Bock, H.G., and Fleischer, S., 1975. Preparation of a homogeneous soluble D-beta-hydroxybutyrate 
apodehydrogenase from mitochondria. J. Biol. chem. 250, 5774-5761.

Bradford, M., 1976. A rapid and sensitive method for the quantitation of microgram quantities of protein utilizing the principle of protein dye binding, Anal. Biochem. 72, 248-254.

Chen, P.S., Torribara, T., Warner, H., 1956. Microdetermination of phosphorus, Anal. Chem. 28, 1756-1758.

Cherkaoui-Malki, M., Kante, A., Demigne, C., Latruffe, N., 1992. Expression of R-3hydroxybutyrate dehydrogenase, a ketone body converting enzyme in heart and liver mitochondria of ruminant and non-ruminant mammals. Comp. Biochem. Physiol. B, 101 (3): 413-20.

Churchill, P., Hempel, J., Romovacek, H., Zhang, W.W., Brennan, M., Churchill, S., 1992. Primary structure of rat liver D-beta-hydroxybutyrate dehydrogenase from cDNA and protein analyses: a short-chain alcohol dehydrogenase. Biochemistry 31, 3793-3799.

Cleland, W.W., 1963. The Kinetics of enzymes catalysed reaction with two or more substrates or products, Nomenclature and rate equations, Biochim. Biophys. Acta 67, 104-107.

El Hilali, M., Veillat, J.P., 1979. Jaculus orientalis: A true Hibernator, Mammalia 39, 401-404.

El Kebbaj, M.S., Berrez, J.M., Lakhlifi, T., Morpain, C., Latruffe, N., 1985. Photolabelling of D- $\beta-$ hydroxybutyrate dehydrogenase with azidoaril phospholipids, FEBS Lett.182, 671-677.

El Kebbaj, M.S., Latruffe, N., 1997. Alkylation at the active site of the D-3- hydroxybutyrate dehydrogenase a membrane phospholipid-dependent enzyme, by 3-chloroacetyl pyridine adenine dinucleotide (3-CAPAD), Biochimie 79, 37-42.

Fleischer, S., Mc Intyre, J.O., Vidal, J.C., 1979. Large-scale preparation of liver mitochondria in high yield. Meths. Enzymol, 55, 32-39.

Gaudemer, Y., Latruffe, N., 1975. Evidence for penetrant and non-penetrant thiol reagents and their use in the location of rat liver mitochondrial D-3-hydroxybutyrate dehydrogenase, FEBS Lett. 54, 30-34.

Gazzoti, P., Bock, H.G.O., Fleischer, S., 1964. Role of lecithin in D-3-hydroxybutyrate dehydrogenase function, Biochem. Biophys. Res. Commun. 58, 309-315.

Hooper, E.T., El Hilali, M., 1972. Temperature regulation and habits in two species of jerboa, genus Jaculus, J. Mammal. 53, 574-593.

Kabine, M., El Kebbaj, M.S., Hafiani, A., Latruffe, N., Cherkaoui-Malki, M., 2003. Hibernation impact on the catalytic activities of the mitochondrial D- $\beta$-hydroxybutyrate dehydrogenase in liver and brain tissues of jerboa (Jaculus orientalis), BMC Biochem. 4-11.

Kante, A., Latruffe, N., Duroc, R., Nelson, B.D., 1987. Import and processing of D- $\beta$ hydroxybutyrate dehydrogenase larger precursor into mitochondria after in vitro translation of free polysomes, Life Sci. Adv. Biochem. 6, 121-123.

Kante, A., Malki, M.C., Coquard, C., Latruffe, N., 1990. Metabolic control of the expression of mitochondrial D-3-hydroxybutyrate dehydrogenase, a ketone body converting enzyme, Biochim. Biophys. Acta. 1033, 291-7.

Kemeny, D., 1991. A practical guide to ELISA, Pergamon Press.

Kielley, W.W., Bronk, J.R., 1958. Oxidative phosphorilation in mitochondrial fragments obtained by sonic vibration, J. Biol. Chen. 230, 521-533.

King, T.E., 1967. Preparation of succinate cytochrome c reductase and cytochrome b-cl particles and reconstitution of succinate-cytochrome c reductase. Meths Enzymol. 10, 216-225.

Laemmli, U.K., 1970. Cleavage of structural proteins during the assembly of the head of bacteriophage T4. Nature 227, 4668-4673.

Latruffe, N., Gaudemer, Y., 1974. Properties and Kinetic mechanism of D-3- hydroxybutyrate dehydrogenase from rat liver submitochondrial particles, Comparatives effects of different thiol reagents, Biochimie 56, 435-444.

Lazarow, P.B., De Duve, C., 1976. A fatty acyl-CoA oxidizing system in rat liver peroxisomes; enhancement by clofibrate, a hypolipidemic drug. Proc. Natl. Acad. Sci. USA 73, 2043-2046.

Lehninger, A.L., Sudduth, H.C., Wise, J.B., 1960. D-3-hydroxybutyric dehydrogenase of mitochondria, J. Biol. Chem. 235, 2450-2455. 
Loeb-Hennard, C., McIntyre, J.O., 2000. (R)-3-hydroxybutyrate dehydrogenase: selective phosphatidylcholine binding by the C-terminal domain. , Biochemistry 39, 11928-11938.

Magnus, T.H., Henderson, N.E., 1988. Thyroid hormone resistance in hibernating ground squirrels, Spermophilus richardsoni. II. Reduction of hepatic nuclear receptors. Gen Comp Endocrinol. 69(3):361-71.

Marks, A.R., McIntyre, J.O., Duncan, T.M., Erdjument-Bromage, H., Tempst, P., Fleischer, S., 1992. Molecular cloning and characterization of (R)-3-hydroxybutyrate dehydrogenase from human heart. J. Biol. Chem. 267, 15459-15463.

McIntyre, J.O., Bock, H.G.O., Fleischer, S., 1978. The orientation of D-3-hydroxybutyrate dehydrogenase in the mitochondrial inner membrane, Biochim. Biophys. Acta 513, 255-267.

McIntyre, J.O., Latruffe, N., Brenner, S.C., Fleischer, S., 1988. Comparison of 3-hydroxybutyrate dehydrogenase from bovine heart and rat liver mitochondria.Arch. Biochem. Biophys. 262, 8598.

McIntyre, J.O., Wang, C.T., Fleischer, S., 1979. The insertion of purified D-beta-hydroxybutyrate apodehydrogenase into membranes. J. Biol. Chem. 254, 5199.

Montoya, R., Ambid, L., and Agid, R., 1979. Comp. Biochem. Physiol. 62, 371-376.

Mountassif, D., Kabine, M., Latruffe, N., El Kebbaj, M.S. (2006) Characterization of two D-betahydroxybutyrate dehydrogenase populations in heavy and light mitochondria from jerboa (Jaculus orientalis) liver. Comp Biochem Physiol B Biochem Mol Biol. 143 (3): 285-293.

Nasser, B., El Kebbaj, M.S., Cottin, P., Latruffe. N., 2002. Purification and characterization of the D-beta-hydroxybutyrate dehydrogenase from dromedary liver mitochondria. Comp. Biochem. Physiol. Biochem. Part B 131 (1): 9-18.

Nielsen, N.C., Zahler, W.L., Fleischer, S., 1973. Mitochondrial D- $\beta$-hydroxybutyrate dehydrogenase: IV. Kinetic analysis of reaction mechanism, J. Biol. Chem. 248, 2556 - 2562.

Raison, J.K. and Lyons, J.M., 1971. Hibernation: alteration of mitochondrial membranes as a requisite for metabolism at low temperature. Proc. Natl. Acad. Sci. USA, 68:2092-2094.

Raison, J.K., 1973. The influence of temperature-induced phase changes on the kinetics of respiratory and other membrane-associated enzyme systems. Bioenergetics 4, 285-309.

Rouser, G., Fleischer, S., 1967. Isolation, Characterization and determination of polar lipids of mitochondria. Meths. Enzymol. 10, 385-406.

Rudy, B., Dubois, H., Mink, R., Trommer, W.E., McIntyre, J.O., Fleischer, S., 1989. Coenzyme binding by 3-hydroxybutyrate dehydrogenase, a lipid-requiring enzyme: lecithin acts as an allosteric modulator to enhance the affinity for coenzyme. Biochemistry 28, 5354-5366.

Sandermann, H., Jr., McIntyre, J.O., Fleischer, S., 1986. Site-site interaction in the phospholipid activation of D-beta-hydroxybutyrate dehydrogenase. J. Biol. Chem. 261, 6201-6208.

Sekuzu, I., Jurtshuk, P., Green, D.E., 1961. Isolation and properties of the D- $\beta$-hydroxybutyrate dehydrogenase of beef heart mitochondria, Biochem. Biophys. Res. Commun. 6, 71-75.

Serrano, A., Mateos, M.I., Losada, M., 1991. Differential regulation by trophic conditions of phosphorylating and non-phosphorylating NADP+-dependent glyceraldehyde-3-phosphate dehydrogenases in Chlorella fusca, Biochem. Biophys. Res. Commun. 181, 1077-1083.

Soukri, A., Hafid, N., Valverde, F., El Kebbaj, M.S. and Serrano, A., 1996. Evidence for a posttranslational covalent modification of liver glyceraldehyde-3-phosphate dehydrogenase in hibernating jerboa (Jaculus orientalis). Biochim. Biophys. Acta, 1292: 177-187.

Soukri, A., Valverde, F., Hafid, N., El Kebbaj, M.S., and Serrano, A., 1995. Characterization of muscle glyceraldehyde-3-phosphate dehydrogenase isoforms from euthermic and induced hibernating Jaculus orientalis. Biochim. Biophys. Acta, 1243:161-168.

Towbin, H., Stahelin, T., Gordon, J., 1991. Electrophoretic transfer of proteins from polyacrylamide gels to nitrocel procedure and applications. Biotechnology 24, 145-149.

Vidal, J.C., Gughelmucci, E.A., Stoppani, A.O.M., 1977. Purification of apo-D-3- hydroxybutyrate dehydrogenase from rat liver mitochrondria. Mol. Cell. Biochem. 16, 153-169.

Wakeman, Dakin, H.D., 1909. On the decomposition of 3-oxybutyric and acetoacetic acid by enzymes of the liver, J. Biol. Chem. 6, 373-389. 
Weekley, L.B., 1995. Tissue and plasma peptidase activity is altered during hypothermic hibernation in the 13 lined ground squirrel (Spermophilus tridecemlineatus). Physiol Behav. 57(3):595-8.

Williamson, D.H., Bates, H.N., Page, M.A., Krebs, H.A., 1971. Activities of enzymes involved in acetoacetate utilization in adult mammalian tissues. Biochem. J. 121, 41-47.

Williamson, D.H., Mellamby, T., and Krebs, H.A., 1962. Enzymatic determination of D-3Hydroxybutyric acid and acetoacetic acid in blood and urine. Biochem. J.82, 90-96.

Wise, J.B., Lehninger, A.L., 1962. The stability of mitochondrial D-3-hydroxybutyric dehydrogenase and its relationships to the respiratory chain. J. Biol. Chem. 237, 1363-1670.

Zhang, W.W., Churchill, P., 1990. Purification of D-beta-hydroxybutyrate dehydrogenase from rat brain.Biochem. Cell Biol. 68, 980-983.

\section{TABLES \& FIGURES}

Table 1

Jerboa plasma analysis at euthermic, prehibernating and hibernating states

\begin{tabular}{|c|c|c|c|}
\hline & Euthermic state & Prehibernating state & Hibernating state \\
\hline D-3-Hydroxybutyrate (mM) & $0.17 \pm 0.03$ & $0.15 \pm 0.05$ & $0.63 \pm 0.09(\times 3.7)^{\mathrm{a}, \mathrm{b}}$ \\
\hline Glucose $\left(\mathrm{g}^{-1}\right)$ & $1.25 \pm 0.12$ & $1.3 \pm 0.11$ & $0.80 \pm 0.09(\times 0.64)^{\mathrm{a}, \mathrm{b}}$ \\
\hline Total cholesterol $\left(\mathrm{g} \mathrm{l}^{-1}\right)$ & $1.11 \pm 0.22$ & $1.17 \pm 0.18$ & $1.68 \pm 0.25(\times 1.51)^{\mathrm{a}}$ \\
\hline HDL cholesterol $\left(\mathrm{g} \mathrm{l}^{-1}\right)$ & $0.74 \pm 0.06$ & $0.80 \pm 0.07$ & $0.94 \pm 0.08(\times 1.27)^{\mathrm{a}}$ \\
\hline LDL cholesterol ( $\left.\mathrm{g} \mathrm{l}^{-1}\right)$ & $0.18 \pm 0.07$ & $0.21 \pm 0.1$ & $0.28 \pm 0.11$ \\
\hline Triglycerides $\left(\mathrm{g}^{-1}\right)$ & $1.44 \pm 0.46$ & $1.66 \pm 0.23$ & $0.81 \pm 0.17(\times 0.56)^{a, b}$ \\
\hline GOT $\left(\mathrm{U}^{-1}\right)$ & $159 \pm 5.65$ & $145 \pm 9.62$ & $143 \pm 6.71$ \\
\hline GPT $\left(\mathrm{U}^{-1}\right)$ & $6 \pm 2.24$ & $8.75 \pm 1.33$ & $6.08 \pm 1.92$ \\
\hline $\mathrm{CPK}\left(\mathrm{U}^{-1}\right)$ & $1143 \pm 280$ & $698 \pm 421$ & $826 \pm 335$ \\
\hline Urea $\left(\mathrm{U}^{-1}\right)$ & $0.38 \pm 0.08$ & $0.36 \pm 0.07$ & $0.65 \pm 0.11(\times 1.7)^{\mathrm{a}, \mathrm{b}}$ \\
\hline Creatinine $\left(\mathrm{U}^{-1}\right)$ & $6.5 \pm 0.07$ & $6.03 \pm 0.05(\times 0.92)^{\mathrm{a}}$ & $7.96 \pm 0.13(\times 1.22)^{\mathrm{a}, \mathrm{b}}$ \\
\hline Total bilirubin $\left(\mathrm{U}^{-1}\right)$ & $8 \pm 3$ & $17.6 \pm 6$ & $41 \pm 11(\times 5.1)^{a, b}$ \\
\hline
\end{tabular}

Values are given as means of four separated experiments \pm standard deviations. Numbers in brackets correspond to the variation compared to the euthermic state.

a Variations statistically significant at $p<0.01$ compared to the euthermic state (ANOVA).

b Variations statistically significant at $p<0.01$ compared to the prehibemating state (ANOVA).

Table 2

Subcellular marker enzyme activities in the heavy and light mitochondrial fractions from jerboa liver compared to liver homogenate at euthermic, prehibernating and hibernating jerboa states

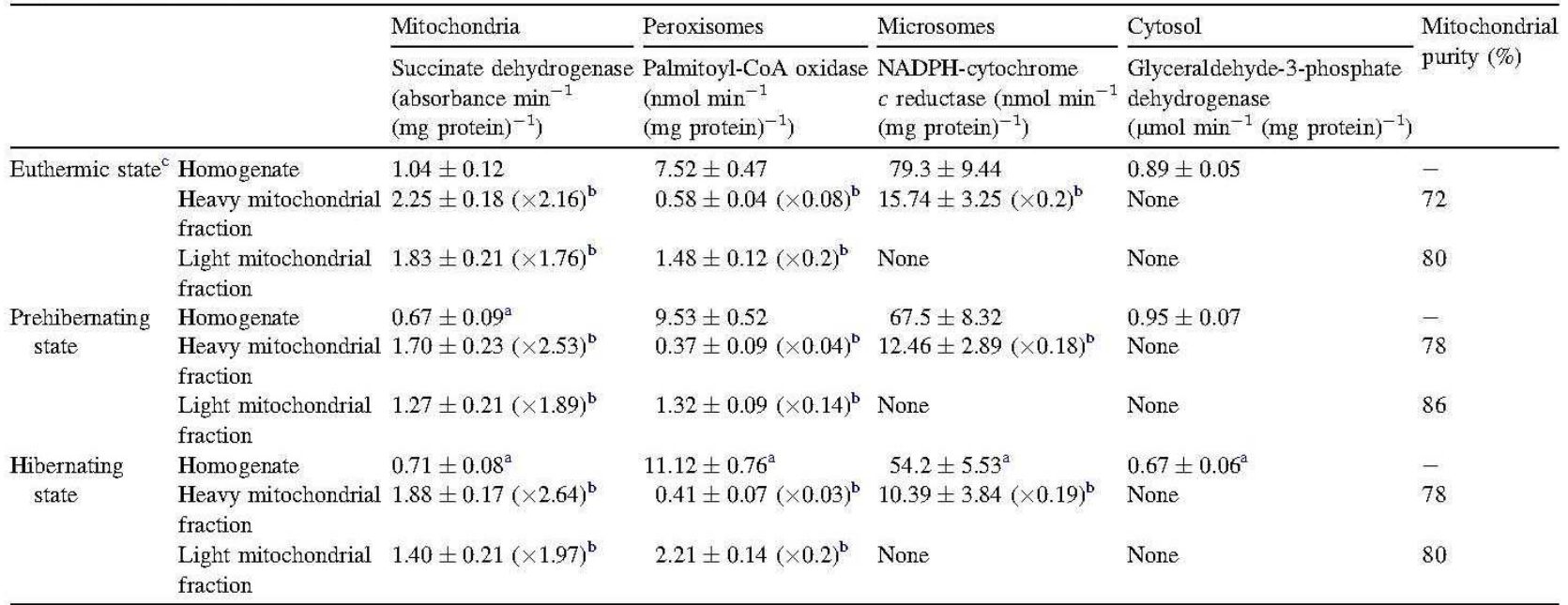

Values are given in specific activities. Values are given as means \pm SD of four separate experiments. Numbers in brackets correspond to the variation compared to homogenate. For experimental conditions, see Section 2.

a Variations statistically significant at $p<0.01$ compared to euthermic state (ANOVA).

b Variations statistically significant at $p<0.01$ compared to homogenate (ANOVA)

${ }^{c}$ Published in Mountassif et al. [10]. 
Table 3

Determination of the kinetic parameters of the liver BDH from heavy and light mitochondria at euthermic, prehibernating and hibernating jerboa states

\begin{tabular}{|c|c|c|c|c|c|}
\hline & & $K_{\mathrm{m}} \mathrm{NAD}^{+}(\mathrm{mM})$ & $K_{\mathrm{m}} \mathrm{BOH}(\mathrm{mM})$ & $K_{\mathrm{D}} \mathrm{NAD}^{+}(\mathrm{mM})$ & $\begin{array}{l}V_{\max }\left(\text { nmol NADH } \min ^{-1}\right. \\
\left.(\mathrm{mg} \text { protein })^{-1}\right)\end{array}$ \\
\hline \multirow[t]{2}{*}{ Euthermic state $^{d}$} & Heavy mitochondria & $0.21 \pm 0.01$ & $1.60 \pm 0.22$ & $1.16 \pm 0.50$ & $0.61 \pm 0.05$ \\
\hline & Light mitochondria & $0.39 \pm 0.03^{c}$ & $3.36 \pm 0.33^{c}$ & $1.66 \pm 0.33$ & $0.22 \pm 0.01^{c}$ \\
\hline \multirow[t]{2}{*}{ Prehibernation state } & Heavy mitochondria & $0.31 \pm 0.03$ & $3.78 \pm 0.21^{\mathrm{a}}$ & $4.75 \pm 0.75^{\mathrm{a}}$ & $0.25 \pm 0.04^{\mathrm{a}}$ \\
\hline & Light mitochondria & $0.24 \pm 0.01^{\mathrm{b}, \mathrm{c}}$ & $4.90 \pm 0.36$ & $2.25 \pm 0.25^{\mathrm{C}}$ & $0.39 \pm 0.06^{b, c}$ \\
\hline \multirow[t]{2}{*}{ Hibernation state } & Heavy mitochondria & $0.25 \pm 0.02$ & $2.77 \pm 0.5$ & $0.32 \pm 0.27^{\mathrm{a}}$ & $1.64 \pm 0.11^{\mathrm{a}}$ \\
\hline & Light mitochondria & $0.35 \pm 0.12$ & $4 \pm 0.94$ & $0.41 \pm 0.32^{\mathrm{b}}$ & $1.85 \pm 0.13^{\mathrm{b}, \mathrm{c}}$ \\
\hline
\end{tabular}

Experiments with varying NAD concentrations $(0.5,1,1.5$ and $2 \mathrm{mM})$ or $\mathrm{BOH}$ concentrations $(2.5,5,7.5$ and $10 \mathrm{mM})$. Values are given as means $\pm \mathrm{SD}$ of three independent experiments. $V_{\max }$ values have been calculated according to the purity of the mitochondrial fractions (Table 1).

${ }^{a}$ Variations statistically significant at $p<0.01$ compared to heavy mitochondria of the euthermic state (ANOVA).

b Variations statistically significant at $p<0.01$ compared to light mitochondria of the euthermic state (ANOVA).

${ }^{c}$ Variations statistically significant at $p<0.01$ between heavy and light mitochondria at the same state.

${ }^{d}$ Published in Mountassif et al. [10].

Table 4

Lipid composition analysis by thin layer chromatography of the heavy and light mitoplasts at euthermic, prehibernating and hibernating jerboa states

\begin{tabular}{|c|c|c|c|c|c|}
\hline & & \multicolumn{4}{|c|}{ Phospholipids (\%) } \\
\hline & & $\mathrm{PE}$ & $\mathrm{PI} / \mathrm{PS}$ & $\mathrm{CL}$ & $\mathrm{PC}$ \\
\hline \multirow[t]{2}{*}{ Euthermic state ${ }^{d}$} & Heavy mitochondria & $28 \pm 6$ & $32 \pm 5$ & $17 \pm 2$ & $23 \pm 3$ \\
\hline & Light mitochondria & $33 \pm 5$ & $38 \pm 4$ & $15 \pm 3$ & $14 \pm 1^{c}$ \\
\hline \multirow[t]{2}{*}{ Prehibernation state } & Heavy mitochondria & $13 \pm 3^{a}$ & $33 \pm 1$ & $24 \pm 2^{a}$ & $30 \pm 2^{a}$ \\
\hline & Light mitochondria & $33 \pm 6^{c}$ & $28 \pm 7$ & $11 \pm 2^{c}$ & $28 \pm 6^{\mathrm{b}}$ \\
\hline \multirow[t]{2}{*}{ Hibernation state } & Heavy mitochondria & $30 \pm 4$ & $34 \pm 6$ & $5 \pm 1^{\mathrm{a}}$ & $31 \pm 6$ \\
\hline & Light mitochondria & $25 \pm 3$ & $34 \pm 4$ & $21 \pm 3^{b, c}$ & $20 \pm 2^{b, c}$ \\
\hline
\end{tabular}

PE, phosphatidyethanolamine; PI, phosphatidylinositol; PS, phosphatidylserine; PC, phosphatidylcholine; CL, cardiolipin. After deposit of $40 \mu \mathrm{g}$ lipid phosphorus of phospholipids, migration and revelation, the amount of phosphorus was measured in each band as described in Section 2 . Values are given as means \pm SD of three independent experiments.

a Variations statistically significant at $p<0.01$ compared to heavy mitochondria of the euthermic state (ANOVA).

b Variations statistically significant at $p<0.01$ compared to light mitochondria of the euthermic state (ANOVA).

${ }^{c}$ Variations statistically significant at $p<0.01$ between heavy and light mitochondria at the same state.

${ }^{d}$ Published in Mountassif et al. [10].

Table 5

BDH activities in the heavy and light mitochondrial fractions from jerboa and rat livers at euthermic, prehibernating and hibernating states

\begin{tabular}{|c|c|c|c|}
\hline & & Jerboa & Rat \\
\hline \multirow[t]{2}{*}{ Euthermic state ${ }^{d}$} & $\begin{array}{l}\text { Heavy mitochondrial } \\
\text { fraction }\end{array}$ & $0.61 \pm 0.05$ & $9.76 \pm 0.4$ \\
\hline & $\begin{array}{l}\text { Light mitochondrial } \\
\text { fraction }\end{array}$ & $0.22 \pm 0.01^{c}$ & $5.21 \pm 0.56^{\mathrm{c}}$ \\
\hline \multirow{2}{*}{$\begin{array}{l}\text { Prehibernating state } \\
\text { for jerboas and cold } \\
\text { with food for rats }\end{array}$} & $\begin{array}{l}\text { Heavy mitochondrial } \\
\text { fraction }\end{array}$ & $0.25 \pm 0.04^{\mathrm{a}}$ & $11.7 \pm 0.46$ \\
\hline & $\begin{array}{l}\text { Light mitochondrial } \\
\text { fraction }\end{array}$ & $0.39 \pm 0.06^{b, c}$ & $12.57 \pm 0.46^{\mathrm{b}}$ \\
\hline \multirow{2}{*}{$\begin{array}{l}\text { Hibernating state } \\
\text { for jerboas and cold } \\
\text { with starvation for rats }\end{array}$} & $\begin{array}{l}\text { Heavy mitochondrial } \\
\text { fraction }\end{array}$ & $1.64 \pm 0.11^{\mathrm{a}}$ & $9.24 \pm 0.2$ \\
\hline & $\begin{array}{l}\text { Light mitochondrial } \\
\text { fraction }\end{array}$ & $1.85 \pm 0.13^{b, c}$ & $11.54 \pm 0.19^{b}$ \\
\hline
\end{tabular}

Values are given in specific activity $\left(\mathrm{nmol} \mathrm{min}^{-1}(\mathrm{mg} \text { protein })^{-1}\right)$. Values are given as means \pm SD of four separate experiments.

${ }^{a}$ Variations statistically significant at $p<0.01$ compared to heavy mitochondria of the euthermic state (ANOVA).

${ }^{b}$ Variations statistically significant at $p<0.01$ compared to light mitochondria of the euthermic state (ANOVA).

${ }^{c}$ Variations statistically significant at $p<0.01$ between heavy and light mitochondria at the same state.

${ }^{d}$ Published in Mountassif et al. [10]. 
$\mathbf{A}_{1}$

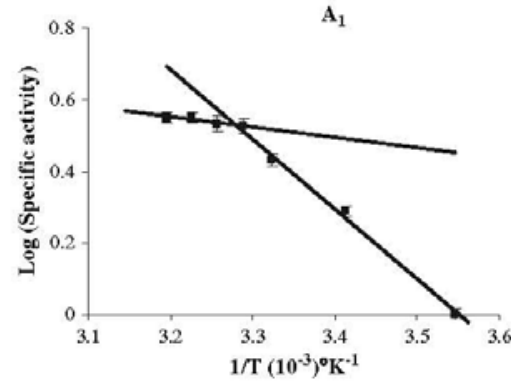

B $_{1}$

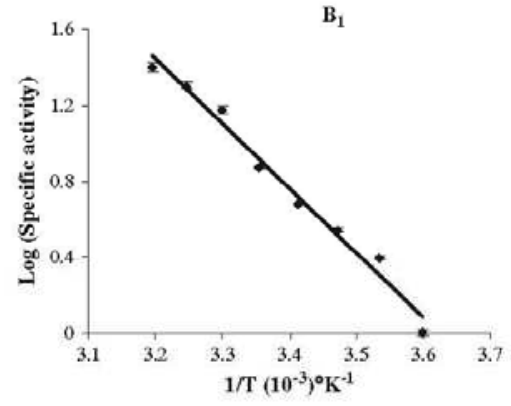

$\mathrm{C}_{1}$

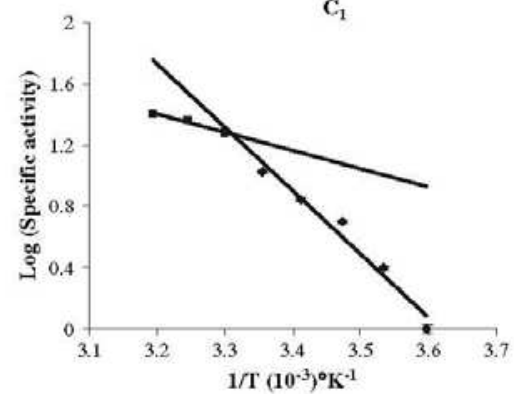

$\mathrm{A}_{2}$

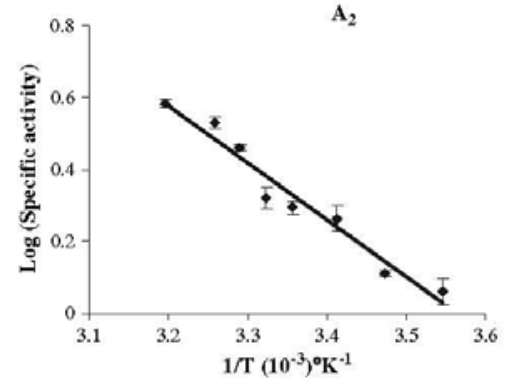

$\mathrm{B}_{2}$

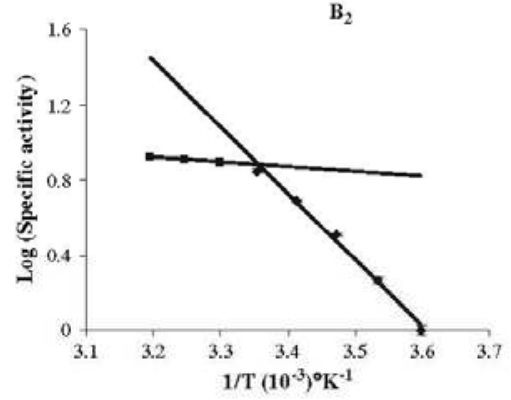

$\mathrm{C}_{2}$

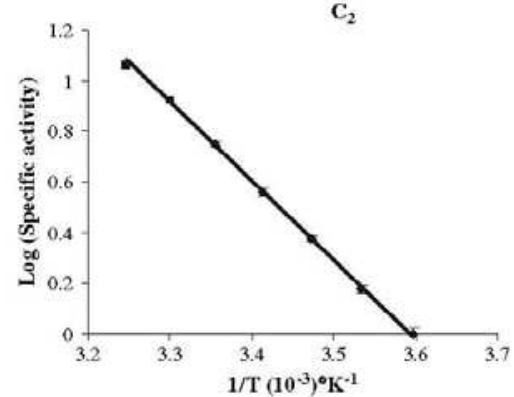

Fig. 1. Arrhenius-plots of the liver BDH from heavy (1) and light (2) mitochondria at euthermic (A) (cf. Mountassif et al. [10]), prehibernating (B) and hibernating (C) jerboa states. Plots were obtained by measuring the enzymatic activity using $100 \mu \mathrm{g}$ of liver mitochondrial protein at various temperatures (from 5 to $40^{\circ} \mathrm{C}$ ). Values are given as mean \pm S.D. of three separate experiments.

A
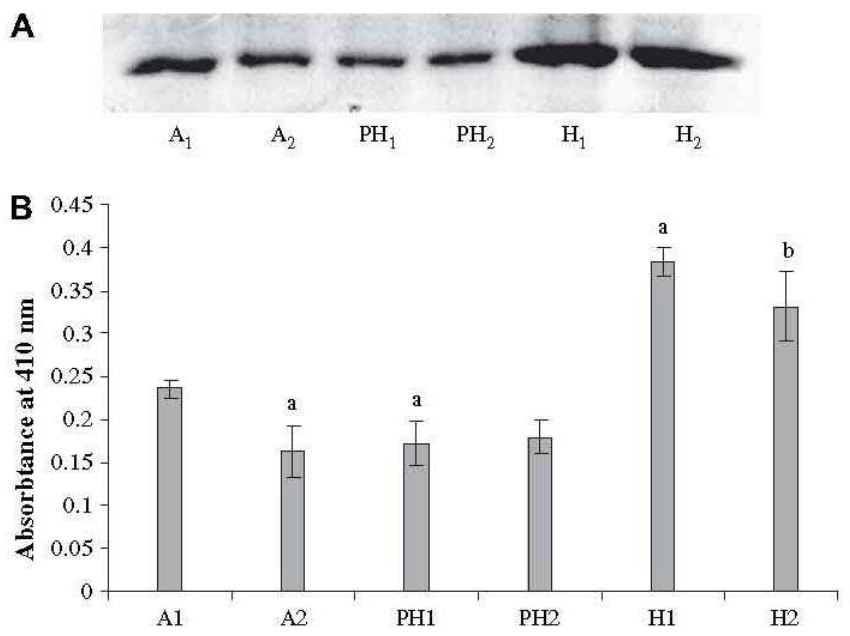

Fig. 2. Western-blotting (A) and ELISA (B) of the liver BDH from heavy and light mitochondria at euthermic (A), prehibernating $(\mathrm{PH})$ and hibernating $(\mathbf{H})$ jerboa states. Western-blotting was assayed with $50 \mu \mathrm{g}$ of proteins and ELISA with $10 \mu \mathrm{g}$ of protein. Lanes represent heavy (1) and light (2) mitochondrial protein fractions from euthermic (A), prehibernating $(\mathrm{PH})$ and hibernating (H) states, respectively. a and b represent significant variations compared to heavy and light mitochondrial protein fractions respectively at euthermic state $(p<0.05$, Student $t$-test). For experimental conditions, see Section 2. 

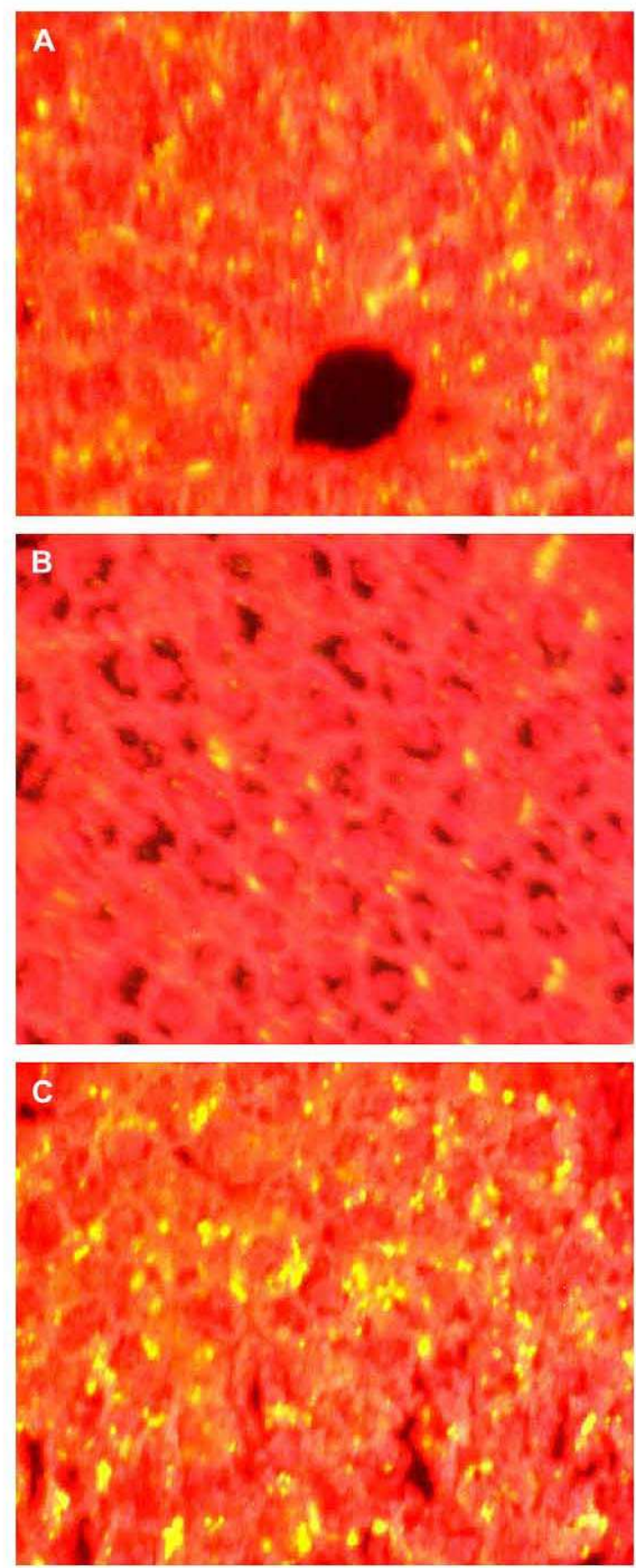

Fig. 3. Immunofluorescence staining and subsequent microscopy of the liver $\mathrm{BDH}$ from euthermic (A), prehibernating (B) and hibernating (C) jerboa states. For experimental conditions, see Section 2. 